\title{
A.JOTE
}

African Journal of Teacher Education

ISSN 1916-7822. A Journal of Spread Corporation

Volume $8019 \quad$ Pages $86-110$

\section{An Assessment of Ghana's Enacted Kindergarten Curriculum}

\author{
Seidu Sofo ${ }^{1}$, Eugene F. Asola ${ }^{2}$ and Reginald Ocansey ${ }^{3}$ \\ ${ }^{1}$ Department of Kinesiology, Nutrition \& Recreation, Southeast Missouri State University, USA \\ 2 Department of Kinesiology \& Physical Education, Valdosta State University, USA \\ ${ }^{3}$ Department of Physical Education \& Sport, University of Ghana, Ghana
}

\begin{abstract}
Drawing on the policy enactment theory, the present study assessed the enacted kindergarten (KG) curriculum in Ghana. Participants were 101 kindergarten teachers in one district of the Upper West Region of Ghana. They completed the Kindergarten Enacted Curriculum Scale (KECS) once. The KECS included 13 items (KG1) and 17 items (KG2) that assessed the extent to which participants taught content in four subscales: literacy and numeracy (LN), psychosocial skills (PS), environmental studies (ES), and physical development (PD). Participants responded to items on a 4point Likert scale as major focus (scored 3), minor focus (scored 2), touched on briefly (scored 1), and not taught (scored 0). Descriptive and inferential statistics were computed for the entire scale and for each subscale. Results indicated that most participants focused on the LN and ES subscales; with the most neglected content areas being the PS and PD subscales. Most KG1 teachers focused on LN (Listening/Speaking-97.7\%), with the lowest percentage in PS (Getting Along/Others25.0\%) and PD (Physical Exercise-29.5\%). Similarly, KG2 teachers focused on ES (Healthy Individual-93.0\%), and the lowest percentage in PS (Knowing/Living with Others-39.3\%) and PD (Spatial Awareness-42.1\%). PS was positively correlated with PD, ES, and KECS. Inferential tests revealed gender differences for the PD subscale. Data indicated grade level differences in teaching $L N$ and PD. These findings suggest that kindergarten teachers in this study continued to focus on academics (LN and ES), despite the emphasis of the KG curriculum being on the holistic development of the young child.
\end{abstract}

\footnotetext{
${ }^{1}$ Corresponding author: ssofo@semo.edu
} 
Keywords: Assessment, curriculum, kindergarten, Ghana, teachers

\section{Introduction}

The United Nations (UN) 2030 Agenda for Sustainable Development Goal 4, Target 4.2 (SDG) stipulates that by 2030, all children should have "access to early childhood education, care, and preprimary education so that they are ready for primary education" (UN, 2015:19). The SDGs seek to build on the Millennium Development Goals (UN, 2013) and what they failed to achieve. Educational change focusing on curriculum reforms has been documented in Sub-Saharan Africa (Bantwini, 2010; Ministry of Education [MOE], 2012) and globally (Flores, 2005; Fullan, 2009). However, many of such curriculum reforms in Sub-Saharan Africa have largely not achieved the intended goals due to their disconnectedness to the African socio-cultural contexts (Tabulawa, 2013).

The planned curriculum or intended (stated) curriculum is the expected content or officially approved curriculum (Gehrke, Knapp, \& Sirotnik, 1992; Porter \& Smithson, 2001). It represents the body of knowledge, ideas, and processes the course designers intend for students to learn and experience in the classroom (Cuban, 1992; Gehrke et al., 1992; Remillard \& Heck, 2014). In contrast, the enacted curriculum is the content teachers implement in their classrooms (Porter \& Smithson, 2001) - it describes the collection of the experiences that students encounter in the classroom (Remillard \& Heck, 2014; Stein, Remillard, \& Smith, 2007). Stein, Grover, and Henningsen (1996) asserted that teachers and students are active agents in curriculum implementation, a process that involves three types of tasks: the task from the curriculum materials, the task as the teacher presents it to the students, and the task as implemented and engaged with by the students (Stein et al., 1996). A third type of curriculum, the attained curriculum, refers to the content students actually learn during the course (Marzano, 2003).

The enacted curriculum is the most important feature of any curriculum indicator system (Porter \& Smithson, 2001; Raudenbush, 2008), because it occurs daily giving children the opportunity to learn (Weisz, 2001). The opportunity to learn, in turn, is a major predictor of student achievement (Hunsader \& Thompson, 2014). The enacted curriculum interacts with numerous aspects of the educational system, from curriculum guides, syllabi, textbooks, and teaching-learning (Cal \& Thompson, 2014). Thus, the intended curriculum rarely aligns with the enacted curriculum in K-12 classrooms (Stein et al., 2007), because the emphasis teachers place on topics, time they allocate for topics and types of learning experiences, for example, impact students' opportunities to 
learn (Hiebert \& Grouws, 2007). There must be harmony between curriculum as written and curriculum as practiced for effective learning to occur (Moore, 2000).

The United Nations International Children's Emergency Fund ([UNICEF], 2012a, 2012b)identified the following basic behaviors and abilities as key to school readiness: pre-literacy and numeracy, ability to follow directions, ability to focus on a learning activity for a given period, and socio-emotional development.Kindergarten education aims at the holistic development of the child. Thus, the physical, cognitive, social, and emotional developments are critical to school readiness(Head Start, 2018).The holistic development of children prepares them for a successful transition to primary learning (UNICEF, 2012a; 2012b). However, research indicates that teachers often neglect the physical (Burgeson, Wechsler, Brener, Young, \&Spain, 2001; Sofo \& Asola, 2015) and psychosocial (Kankam \& Abroampa, 2016) domains of development for young children. Early childhood teachers need to be well-prepared to teach these two domains, in view of their invaluable contribution to the development and learning of children.

The Ghanaian kindergarten curriculum seeks to develop the physical domain through gross and fine motor skills, perceptual-motor skills, and sports and games (Ministry of Education, Science and Sports[MOESS], 2006). Physical play through movement centers and outdoor play in early childhood contexts plays an important role in this regard. Not only does outdoor play, for example, benefit children's physical, cognitive, and social-emotional development (Bullard, 2012; Frost, Brown, Sutterby, \& Thornton, 2004), but it also serves as a pathway for children to interact, develop friendships, and release stress (Wells \& Evans, 2003). Physical inactivity leads to diseases such as childhood obesity and should be a major public health concern since obese children would likely be obese as adults (Martyniuk \&Tucker, 2014). Often, obese children are discriminated against due to their nutritional status. Consequently, they tend to develop low self-image that persists into adulthood (Dietz,1998). Furthermore, early childhood educators lack movement-related teaching skills, and often use inappropriate practices in teaching movement (Burgeson et al., 2001).

Children's ability to self-regulate gives them a sense of self-control and successful peer relationships, helping them to get along with others (Onchwari \& Keengwe, 2011). Also, social competence helps children in negotiating the complex world of peers. To enhance children's psychosocial skills, parents and teachers need to provide opportunities for children to play with their peers (Mize \& Abell, 1996). The role of social competence in young children's school readiness and 
academic success is widely recognized; however, research supporting early childhood teachers in that regard are scarce (Fox, Hemmeter, Snyder, Binder, \& Clarke, 2011).

Curriculum delivery is affected by factors such as teacher beliefs, knowledge, attitudes, competencies, space and facilities, time constraints, the role of school principal as an instructional leader, students' ability level and interests (Kruse \& Roehrig, 2005; Roehrig, Kruse \& Kern, 2007; Son \& Senk, 2014). Weiss et al. (2003), for example, reported the most influence on teacher pedagogy among K-12 teachers were teachers' beliefs, knowledge, experiences and characteristics. Not only do teacher beliefs affect what teachers select to teach, but also the way they teach (Capel \& Blair, 2013). Further, the school cultural context has a powerful influence on the actual teaching practices; new teachers come to understand the school culture through interactions with colleagues (Brouwer, \& Korthagen, 2005; Christensen, 2013).

\section{Theoretical Framework}

The alignment between the intended and enacted curriculum is necessary for effective learning outcomes to occur (Moore, 2000). However, the intended curriculum rarely aligns with the enacted curriculum in K-12 classrooms (Stein et al., 2007). Therefore, there is a need for harmony between the intended curriculum (the content), and the context or environment in which the implementation takes place (Chapman, Wright, \& Pascoe, 2017). Thus, the policy enactment theory (Ball, Maguire, \& Braun, 2012) provides an appropriate theoretical framework for the present study. According to Ball et al. (2012), four contextual variables impact schools' ability to implement the intended curriculum. The contextual dimensions included: situated contexts, professional cultures, material contexts, and external factors.

Situated contexts refer to the environment or the location and population in which the school is located. Context factors such as class size and social amenities, for example, affect the ability of teachers to enact the planned curriculum (Ball et al., 2012). For example, opportunities for educational activities would be difficult to access in rural areas. Schools with access to social amenities such as electricity, internet, and health facilities would have easier access to educational resources than schools without these amenities.

Professional school cultures such as management style, and supervision of teachers (Brouck, 2008) availability of qualified teachers and resources impact the extent to which teachers implement the intended curriculum (Ball et al., 2012). In addition, school leaders such as head 
teachers/headmasters influence teachers' enactment by shaping access to policy ideas, the interpretation of the intended curriculum, and creating conditions for professional development in schools (Coburn, 2005).

Material contexts refer to such factors as personnel, and infrastructure available to the school (Ball et al., 2012). The layout of the classroom space affects, for example, the availability of space for learning centers and playgrounds in the kindergarten environment. These, in turn, greatly impact the extent to which teachers implement the planned curriculum.

External factors are those factors that are outside the control of the teacher (Ball et al., 2012).For example, teachers often are unable to complete overloaded teaching syllabi in the planned curriculum (Sabol, 2013). In addition, expectations of parents and society to prepare children to be academically ready for primary school can influence the type of curriculum teachers implement in their kindergarten classrooms(Ball et al., 2012). The intended Ghanaian kindergarten curriculum (MOESS, 2006) is an external document, and an understanding of the four contextual dimensions is crucial in its implementation in the classroom (Chapman, et al, 2017).

\section{Enacted curriculum research in Ghana}

Studies on the kindergarten enacted curriculum in Ghana are scarce. Most studies were conducted in the primary, or high school or tertiary contexts. First, Mereku (1995) compared the official Ghanaian primary mathematics curriculum with the way it was implemented. Results indicated that coverage of textbooks influenced the emphasis placed on topics covered in the classroom. There was no significant difference in the content emphasized in the intended curriculum and the enacted curriculum. Similarly, delivery of content through whole-class teaching was evident in both the intended and enacted curricula (Mereku, 1995).

Second, Boahin and Hofman (2012) investigated the effectiveness of competency-based training (CBT) implementation in Ghanaian polytechnics and industry. While the method of instruction in CBT must be learner-centered, the participating institutions overly relied on lecture notes and assignments, with lesson delivery was generally lecture-centered. In addition, the preparation of teaching and learning materials was the sole responsibility of the lecturers, with no input from students as required in a CBT program (Boahin \& Hofman, 2012). 
In a third study, Kwarteng (2018) examined the quality of use of the accounting curriculum among high school teachers in Ghana. The quality of use was influenced by teachers' perceived relevance of the curriculum, level of difficulty of topics, availability of teaching aids, interest of the teacher, and availability of curriculum materials. In addition, the freedom or autonomy offered teachers to implement the curriculum shaped the enacted curriculum (Kwarteng, 2018).

Fourth, Mereku and Mereku (2015) examined the congruence between the intended and implemented information and communication technology (ICT) curricula in six African countries including Ghana. The classroom practice revealed that only teachers who taught ICT as a subject used technology to a limited extent. In addition, teachers focused on students developing skills in operating ICT, rather than developing students' ICT literacy. Further, gaps existed between the intended and attained curricula and between implemented attained curricula (Mereku \& Mereku, 2015).

Fifth, McCoy and Wolf (2018) used a culturally validated instrument to examine how changes in $\mathrm{KG}$ classroom quality predicted early academic and social-emotional skills over a period of one academic year in the Greater-Accra Region of Ghana. Results showed improvement in classroom instructional quality resulted in small and positive gains in children's early academic and socialemotional outcomes. However, the relationship between changes in the social-emotional aspects of classroom quality and child outcomes were mixed (McCoy \& Wolf, 2018).

Sixth, Wolf (2017) evaluated a Fast Track Transformational Teacher Training Program (FTTT) among a group of KG student teachers in the Western Region of Ghana. The preliminary results showed that the FTTT improved student teachers' knowledge and implementation of the KG curriculum. In addition, FTTT teachers had higher levels of motivation and feelings of personal accomplishment than non-FTTT teachers. In contrast, FTTT teachers had lower levels of job satisfaction when they became full-time teachers. On a negative note, the improvements from the FTTT program did not translate into improved child learning or development outcomes one year after the student teachers became full-time teachers (Wolf, 2017).

Finally, Wolf, Aber, Behrman, and Tsinigo (2018) implemented the Quality Preschool for Ghana (QP4G) project aimed at building capacity and improving the implementation of the Ghanaian KG curriculum. The QP4G resulted in improving student expression, emotional support and behavior management, but not facilitating deeper learning. In addition, teachers incorporated play- 
based and child-centered strategies and appropriate classroom-management skills in their classrooms. Furthermore, the intervention resulted in reducing teacher burnout and improving children's school readiness (Wolf et al., 2018).

The preceding review revealed some level of incongruence between the intended and enacted curriculum in Ghana. Also, the review provided evidence that it is possible to impact KG teachers' knowledge, skills, and effectiveness in the classroom. More research on the extent to which $\mathrm{KG}$ teachers implement the intended kindergarten content (topics) in Ghanaian classrooms is necessary. That is, more studies are needed to examine what topics or content teachers cover in their $\mathrm{KG}$ classrooms.

\section{Purpose of the Study}

Educational policymakers, textbook publishers, and teachers often focus on content coverage and learning activities without regard to educational goals. As Bouck (2008) pointed out, contextual, organizational, micropolitical and individual factors influence the enacted curriculum. Therefore, the purpose of the present study was to assess the enacted kindergarten curriculum in Ghana. Specifically, it examined the extent to which teachers implemented the kindergarten intended curriculum in their classrooms. Providing students opportunities to learn specific topics in the curriculum are critical to student learning (Rowan, Camburn, \& Correnti, 2004). Gaining insight into the content teachers teach or neglect would allow educational administrators to work with teachers to provide a balanced curriculum in $\mathrm{KG}$ classrooms.

\section{Research Questions}

The present study was guided by three underpinning research questions:

1. What content (topics) are Ghanaian teachers' major focus in the enacted kindergarten curriculum?

2. What are the correlates of the enacted kindergarten curriculum in Ghana?

3. To what extent do teacher gender, pupil grade level, and teacher professional qualification affect the enacted kindergarten curriculum in Ghana? 


\section{Method}

\section{Participants}

Participants included a purposive sample of 101 (32 males; 68 females; one did not indicate gender) kindergarten teachers in one district of the Upper West Region of Ghana. Participants were 44 and 57 KG1 and KG2 teachers respectively. They taught class sizes ranging from 12-159 (M=47.2; SD = 30.2). Participants had teaching experiences ranging from one to 30 years $(\mathrm{M}=4.07$; $\mathrm{SD}=5.31)$. Overall, the sample included 17 untrained teachers, 4 with Post-Secondary Certificates, 70 with Diplomas, and 10 with Bachelor's Degrees. The breakdown for KGI teachers were Untrained (7), Post-Secondary Certificate (2), and Diploma (35). The KG2 teachers consisted of Untrained (10), Post-Secondary Certificate (2), Diploma (35), and Bachelor's Degree (10).

To maintain their teaching positions for extended periods of time, untrained teachers enrol in the Untrained Teachers Diploma in Basic Education (UTDBE) program in addition to the mandated professional development in basic schools. The objective of the UTDBE program is to upgrade the content knowledge and teaching methods of untrained teachers (Ministry of Education, 2012). The program consists of a 4-year school-based professional development, distance learning modules, and periodic residential sessions on the campus of trainees' respective colleges of education (Ghana Education Service, 2003). The program allows untrained teachers to prepare to become certified teachers without leaving their respective classrooms when schools are in session. Thus, UTDBE teachers have had some teaching experience and have acquired some pedagogical skills (Kwaah, \& Palojoki, 2018).

\section{Instrument}

The authors developed the Kindergarten Enacted Curriculum Scale (KECS) for the study. Participants provided demographic information on teaching experience, number of years teaching $\mathrm{KG}$, grade level, gender, class size, and professional qualification. In addition, the KECS included 13 items (KG1) and 17 items (KG2) that assessed the extent to which participants taught content in four subscales: Literacy and Numeracy (LN), Psychosocial Skills (PS), Environmental Studies (ES), and Physical Development (PD). The items for each subscale were content adapted from the kindergarten stated or intended curriculum (MOESS, 2006). Sample items for the LN, PS, ES, and PD subscales (KG1) were Listening/Speaking, Responsibilities, Healthy Individual, and Physical Exercise respectively. Participants responded to the items on a 4-point Likert scale as major focus (scored 3), 
minor focus (scored 2), touched on briefly (scored 1), and not taught (scored 0). A higher score indicated alignment with the kindergarten curriculum and a lower score indicated non-alignment. The authors adapted the descriptors for the 4-point Likert scale from Rowan, et al. (2004). The KECS for KG1 and KG 2 had Cronbach's Alphas of .728 and .839 respectively.

The present study, to the best of our knowledge, is the first attempt to investigate the content that served as Ghanaian kindergarten teachers' major focus. The major strength of the KECS was that it utilized content in the Ghanaian kindergarten intended curriculum. However, a major limitation of the methodology of the present study was that it did not assess the quality of the enacted curriculum. Another limitation relates to the use of a self-report questionnaire. The study did not examine curriculum documents such as unit and lesson plans as evidence of the content teachers covered in their classrooms.

\section{Data Collection and Analysis}

The Human Subjects Committee at the first author's institution approved the study. In addition, written permission to conduct the study in the schools was obtained from the District Directorate of Education responsible for the schools involved in the study. Finally, the teachers provided written informed consent prior to completing the questionnaire. Participants were at the time of the study attending a one-day workshop organized by the District Directorate of Education during the third term of the academic year. Out of 120 kindergarten teachers in the school district, $101(84.17 \%)$ agreed to participate in the study. The first author distributed the questionnaire to the teachers at the site for the workshop and collected the completed questionnaires the same day at the end of the workshop.

A major limitation of the use of purposive sampling for the study was that the sample was not representative of kindergarten teachers in Ghana. However, it was representative of kindergarten teachers in the district that served as the site for the study as the sample constituted $84.17 \%$ of the kindergarten teacher population in the district.

Descriptive and inferential data were computed for the entire scale and for each subscale. First, the authors determined the frequencies and percentages of teachers for each item for major focus, minor focus, touched briefly, and not taught. The total number of responses for some items did not add up to 101 because some participants did not respond to all items on the questionnaire. Second, correlation matrices were computed for teaching experience, experience teaching KG class, 
each subscale, and KECS (overall scale). Third, Independent Samples t-Test analyses were conducted for gender, the four subscales, and KECS. Fourth, Independent Samples t-Test analyses were computed comparing each subscale and KECS for KG1 and KG2. Finally, a One-Way ANOVA was done for professional qualification, the subscales, and KECS.

\section{Results}

\section{Content focus and the enacted curriculum}

The first research question examined the content (topics) Ghanaian teachers focused on in the enacted kindergarten curriculum. Tables 1 shows data on the content teachers focused on in the enacted KG1 curriculum. The data indicate that the highest percentage of KG1 teachers had a major focus on Listening/Speaking (97.7\%) and Pre-reading (95.5\%), both in the LN subscale. Alternatively, the lowest percentage of the teachers had as their major focus contents in PS (Getting Along with Others- 25.0\%; Self-Awareness/Responsibilities- 34.1\%). The PS and PD subscales were the most neglected by KG1 teachers. For example, $43.2 \%$ of the teachers did not teach or only briefly touched these contents (Self-Awareness-PS and Physical Exercise-PD).

Table 1: Percentages of teachers and the focus for each content in KG1

\begin{tabular}{|c|c|c|c|c|}
\hline Content & $\begin{array}{l}\text { A Major } \\
\text { Focus }\end{array}$ & A Minor Focus & $\begin{array}{l}\text { Touched } \\
\text { Briefly }\end{array}$ & Not Taught \\
\hline Literacy/Numeracy & $\mathrm{f} / \%$ & $\mathrm{f} / \%$ & $\mathrm{f} / \%$ & $\mathrm{f} / \%$ \\
\hline Listening/Speaking & $43(97.7)$ & $1(2.3)$ & $0(.00)$ & $0(.00)$ \\
\hline Pre-reading Activities & $42(95.5)$ & $2(4.5)$ & $0(.00)$ & $0(.00)$ \\
\hline Pre-Writing & $36(76.7)$ & $3(14.0)$ & $4(9.3)$ & $4(9.10)$ \\
\hline Number/Numerals & $40(90.9)$ & $3(6.8)$ & $1(2.3)$ & $0(.00)$ \\
\hline Classification & $41(93.2)$ & $3(6.8)$ & $0(.00)$ & $0(.00)$ \\
\hline \multicolumn{5}{|l|}{ Psychosocial skills } \\
\hline Self-Awareness & $15(34.1)$ & $10(22.7)$ & $11(25.0)$ & $8(18.20)$ \\
\hline $\begin{array}{l}\text { Getting Along with } \\
\text { Others }\end{array}$ & $11(25.0)$ & $16(36.4)$ & $11(25.0)$ & $6(13.6)$ \\
\hline Responsibilities & $15(34.1)$ & $17(38.6)$ & $4(9.1)$ & $8(18.20)$ \\
\hline Coping with Emotions & $26(59.1)$ & $6(13.6)$ & $8(18.2)$ & $3(6.80)$ \\
\hline Environmental Studies & & & & \\
\hline
\end{tabular}




\begin{tabular}{|c|r|r|r|r|}
\hline Healthy Individual. & $35(79.5)$ & $2(4.5)$ & $6(13.6)$ & $1(2.30)$ \\
\hline Physical Environment. & $38(86.4)$ & $5(11.4)$ & $1(2.3)$ & $0(.00)$ \\
\hline Social Environment & $33(75.0)$ & $3(6.8)$ & $5(11.4)$ & $3(6.80)$ \\
\hline Physical Development & & & & \\
\hline Physical Exercise & $13(29.5)$ & $12(27.3)$ & $8(18.2)$ & $11(25.00)$ \\
\hline
\end{tabular}

$\mathrm{f} / \%=$ Frequency $/$ Percentage

Tables 2 presents data on the content teachers focused on in the enacted KG2 curriculum. The results indicated that most KG2 teachers focused on ES (Healthy Individual- 93.0\%) and LN (Pre-reading-91.2\%; Listening/Speaking- 89.5\%). Alternatively, only $39.3 \%$ and $47.2 \%$ of the teachers focused on PS (Knowing-Living with Others and Coping with Emotions respectively). For example, $34.0 \%$ and $35.1 \%$ of KG2 teachers did not teach or only touched briefly, Coping with Emotions-PS and Sensory Motor Skills-PD respectively.

Table 2:Percentages of teachers and the focus for each content in KG2

\begin{tabular}{|c|c|c|c|c|}
\hline Content & $\begin{array}{l}\text { A } \quad \text { Major } \\
\text { Focus }\end{array}$ & $\begin{array}{l}\text { A Minor } \\
\text { Focus }\end{array}$ & $\begin{array}{l}\text { Touched } \\
\text { Briefly }\end{array}$ & Not Taught \\
\hline Literacy/Numeracy & $f / \%$ & $\mathrm{f} / \%$ & $\mathrm{f} / \%$ & $\mathrm{f} / \%$ \\
\hline Listening/Speaking & $51(89.5)$ & $5(8.8)$ & $0(.0)$ & $1(1.8)$ \\
\hline Pre-reading Activities & $52(91.2)$ & $3(5.3)$ & $1(1.8)$ & $1(1.8)$ \\
\hline Pre-writing & $42(73.7)$ & $11(19.3)$ & $4(7.0)$ & $0(.0)$ \\
\hline Numbers/Numerals & $40(70.2)$ & $13(22.8)$ & $2(3.5)$ & $2(3.5)$ \\
\hline Classification & $46(80.7)$ & $8(14.0)$ & $3(5.3)$ & $0(.0)$ \\
\hline \multicolumn{5}{|l|}{ Psychosocial Skills } \\
\hline $\begin{array}{l}\text { Knowing/Living with } \\
\text { Others }\end{array}$ & $22(39.3)$ & 17(30.4) & $5(8.9)$ & $12(21.4)$ \\
\hline Responsibilities & $29(51.8)$ & $10(17.9)$ & $8(14.3)$ & $9(16.1)$ \\
\hline Coping with Emotions & $25(47.2)$ & $10(18.9)$ & $10(18.9)$ & $8(15.1)$ \\
\hline Decision-Making & $27(49.1)$ & $11(20.0)$ & $10(18.2)$ & $7(12.7)$ \\
\hline \multicolumn{5}{|l|}{ Environmental Studies } \\
\hline Healthy Individual- & $53(93.0)$ & $2(3.5)$ & $1(1.8)$ & $1(1.8)$ \\
\hline Physical Environment & $37(64.9)$ & $17(29.8)$ & $3(5.3)$ & $0(.00)$ \\
\hline Social Environment & $37(64.9)$ & 11(19.3) & $4(7.0)$ & $5(8.8)$ \\
\hline
\end{tabular}




\begin{tabular}{|l|r|r|r|r|}
\hline Physical Development & & & & \\
\hline Gross Motor Skills & $49(85.9)$ & $5(8.8)$ & $3(5.3)$ & $0(.00)$ \\
\hline Fine Motor Skills & $37(64.9)$ & $14(24.6)$ & $4(7.0)$ & $2(3.5)$ \\
\hline Spatial Awareness & $24(42.1)$ & $11(19.3)$ & $13(22.8)$ & $9(15.8)$ \\
\hline Sensory Motor Skills & $31(54.4)$ & $6(10.5)$ & $11(19.3)$ & $9(15.8)$ \\
\hline Sports and Games & $29(50.9)$ & $15(26.3)$ & $9(15.8)$ & $4(7.0)$ \\
\hline
\end{tabular}

$\mathrm{f} / \%=$ Frequency/Percentage

\section{Correlation matrices}

The second research questions investigated the correlates of the enacted kindergarten curriculum in Ghana. Table 3 shows correlation matrices for teaching experience, experience teaching kindergarten, class size, the subscales, and KECS. The matrix for KG1 indicated that class size had significant negative correlation with the PS, PD, and ES subscales. In addition, teaching experience and number of years teaching KG1 negatively correlated with PS. Furthermore, PS was positively correlated with PD, ES, and KECS.

The matrix for KG2 revealed that class size did not correlate with any of the subscales. Teaching experience positively correlated with PD. In addition, PS was positively correlated with PD, ES, and KECS.

Table 3: Correlation matrices for KG1 and KG2

\begin{tabular}{|l|c|c|c|c|c|c|c|}
\hline Category & 2 & 3 & 4 & 5 & 6 & 7 & 8 \\
\hline KG 1 & & & & & & & \\
\hline Teaching Exprience-1 & .271 & -.036 & -.113 & $-.310^{*}$ & -.248 & .140 & -.215 \\
\hline $\begin{array}{l}\text { Experience Teaching } \\
\text { KG1-2 }\end{array}$ & & $.482^{* *}$ & -.288 & $-.344^{*}$ & -.018 & -.107 & -.188 \\
\hline Class Size-3 & & & -.123 & $-.670^{* *}$ & $-.377^{*}$ & $-.456^{* *}$ & $-.618^{* *}$ \\
\hline Literacy/Numeracy-4 & & & & -.107 & .121 & .170 & .070 \\
\hline Psychosocial Skills-5 & & & & & $.443^{* *}$ & $.354^{*}$ & $.766^{* *}$ \\
\hline $\begin{array}{l}\text { Physical } \\
\text { Developmen-6 }\end{array}$ & & & & & & $.511^{* *}$ & $.864^{* *}$ \\
\hline $\begin{array}{l}\text { Environmental } \\
\text { Studies-7 }\end{array}$ & & & & & & & $.727^{* *}$ \\
\hline \begin{tabular}{l} 
KECS-8 \\
\hline
\end{tabular}
\end{tabular}




\begin{tabular}{|l|r|r|r|r|r|r|r|}
\hline & & & & & & & \\
\hline KG 2 & & & & & & & \\
\hline Teaching Exprience-1 & $.661^{* *}$ & .170 & .076 & .098 & $.315^{* *}$ & -.159 & -.128 \\
\hline $\begin{array}{l}\text { Experience Teaching } \\
\text { KG2-2 }\end{array}$ & & $.388^{* *}$ & .082 & .136 & .041 & .071 & .066 \\
\hline Class Size-3 & & & .247 & .041 & .132 & -.260 & -.237 \\
\hline Literacy/Numeracy-4 & & & & .159 & $.286^{* *}$ & .099 & .136 \\
\hline Psychosocial Skills-5 & & & & & $.433^{* *}$ & $.412^{* *}$ & $.464^{* *}$ \\
\hline $\begin{array}{l}\text { Physical } \\
\text { Developmen-6 }\end{array}$ & & & & & & .189 & $.299^{*}$ \\
\hline $\begin{array}{l}\text { Environmental } \\
\text { Studies-7 }\end{array}$ & & & & & & & $.991^{* *}$ \\
\hline KECS -8 & & & & & & & \\
\hline
\end{tabular}

$$
* \mathrm{p}<.05 ; * * \mathrm{p}<.01 .
$$

\section{Gender and enacted curriculum}

The first part of the third research questions determined to what extent gender affected the enacted kindergarten curriculum in Ghana. Table 4 presents data on gender, subscales, and KECS (Overall Scale) for both KG1 and KG2. There was a significant difference for PD $(t=2.86 ; p=.005)$. Male teachers had a higher mean score (2.40) than their female counterparts (1.82). Overall, male teachers were more likely than female teachers to have Physical Development as their major focus.

Table 4: Independent Samples t-Test analysis for gender, subscales and overall scale

\begin{tabular}{|c|c|c|c|c|}
\hline Category & $\begin{array}{l}\text { Male } \\
(\mathrm{n}=32)\end{array}$ & Females $(\mathrm{n}=68)$ & $\mathrm{t}$-value & \\
\hline & $\mathrm{M}(\mathrm{SD})$ & $\mathrm{M}(\mathrm{SD})$ & $\mathrm{t}$ & $\mathrm{P}$ \\
\hline Literacy/Numeracy & $2.78(.27)$ & $2.83(.22)$ & -.92 & .358 \\
\hline Psychosocial Skills & $1.84(.94)$ & $1.98(.83)$ & -.71 & .479 \\
\hline Environmental Studies & $2.58(.51)$ & $2.67(.43)$ & -.85 & .397 \\
\hline Physical Development & $2.40(.64)$ & $1.82(1.05)$ & 2.86 & $.005^{* *}$ \\
\hline KECS & $2.52(.53)$ & $2.34(.59)$ & .15 & .159 \\
\hline
\end{tabular}

$* * \mathrm{p}<.01$

\section{Grade level and enacted curriculum}


The second part of the third of the research questions examined the extent to which grade affected the enacted kindergarten curriculum in Ghana. Table 5 presents data on the enacted curriculum for KG1 and KG2. The results showed significant grade level differences for LN, PD, and KECS. Teachers in KG1 had a higher mean score (2.88) than KG2 (2.75) on LN. Conversely, KG2 teachers had higher mean scores on PD and KECS than those teaching KG1. There were no significant grade level differences for PS and ES.

Table 5: Independent Samples t-Test analyses comparing subscales and KECS for KG1 and KG2

\begin{tabular}{|l|c|c|c|c|}
\hline Category & $\begin{array}{c}\text { KG1 } \\
(\mathrm{n}=44)\end{array}$ & $\begin{array}{c}\text { KG2 } \\
(\mathrm{n}=57)\end{array}$ & \multicolumn{2}{|c|}{ t-value } \\
\hline & $\mathrm{M}(\mathrm{SD})$ & $\mathrm{M}(\mathrm{SD})$ & $\mathrm{T}$ & $.005^{* *}$ \\
\hline Literacy/Numeracy & $2.88(.15)$ & $2.75(.28)$ & 2.85 & .847 \\
\hline Psychosocial Skills & $1.93(.80)$ & $1.95(.92)$ & -.194 & .998 \\
\hline Environmental Studies & $2.65(.39)$ & $2.64(.50)$ & -.003 & $.000^{* * *}$ \\
\hline Physical Development & $1.61(1.17)$ & $2.33(.65)$ & -3.93 & $.000^{* * *}$ \\
\hline KECS & $2.18(.57)$ & $2.58(.52)$ & -3.78 & \\
\hline
\end{tabular}

$* * \mathrm{p}<.01 ; * * * \mathrm{p}<.001$

\section{Professional qualification, subscales and KECS}

The third part of the third research question examined the extent to which professional qualification affected the enacted kindergarten curriculum in Ghana. Table 6 shows data on professional qualification and enacted curriculum for both KG1 and KG2. There were significant differences between untrained teachers and those with diplomas on PS, ES, PD, and KECS for KG1. Untrained teachers had higher mean scores on the three subscales and KECS. Similarly, the untrained teachers had significantly higher mean scores than their counterparts with postsecondary certificates on PS and KECS. The mean scores for KGI teachers with the different professional qualifications on the LN subscale did not differ.

Data for KG2 revealed significant mean differences between untrained teachers and those with diplomas and bachelor's degrees on the PS subscale. The untrained teachers had higher mean scores on the PS subscale than their counterparts with diplomas or bachelor's degrees. In addition, the untrained teachers had a significant higher mean score than those with bachelor's 
degrees on the PD subscale. Mean scores for KG2 teachers on the LN and ES subscales and KECS for all categories of professional qualifications were similar.

Table 6: One-Way ANOVA for professional qualification and overall mean score

\begin{tabular}{|l|c|c|c|c|c|c|}
\hline Category & Untrained & $\begin{array}{l}\text { Post-Sec } \\
\text { Cert }\end{array}$ & Diploma & $\begin{array}{l}\text { Bachelor's } \\
\text { Degree }\end{array}$ & F-value & P-value \\
\hline KG1 & $\mathrm{M}(\mathrm{SD})$ & $\mathrm{M}(\mathrm{SD})$ & $\mathrm{M}(\mathrm{SD})$ & $\mathrm{M}(\mathrm{SD})$ & $\mathrm{F}$ & $\mathrm{p}$ \\
\hline Literacy/Numeracy & $2.91(.16)$ & $2.90(.14)$ & $2.87(.15)$ & $\mathrm{N} / \mathrm{A}$ & .147 & .864 \\
\hline $\begin{array}{l}\text { Psychosocial Skills } \\
\text { Studies }\end{array}$ & $2.68(.35)$ & $1.63(.18)$ & $1.80(.81)$ & $\mathrm{N} / \mathrm{A}$ & 4.14 & $.023^{*}$ \\
\hline $\begin{array}{l}\text { Physical } \\
\text { Development }\end{array}$ & $3.00(.00)$ & $2.67(.00)$ & $2.65(.39)$ & $\mathrm{N} / \mathrm{A}$ & 3.73 & $.032^{*}$ \\
\hline KECS & $2.57(.53)$ & $2.50(.71)$ & $1.37(1.16)$ & $\mathrm{N} / \mathrm{A}$ & 4.26 & $.021^{*}$ \\
\hline KG2 & $2.80(.22)$ & $2.31(.23)$ & $2.05(.54)$ & $\mathrm{N} / \mathrm{A}$ & 6.56 & $.003^{* *}$ \\
\hline Literacy/Numeracy & $2.70(.17)$ & $2.90(.14)$ & $2.78(.29)$ & $2.64(.35)$ & .95 & .420 \\
\hline $\begin{array}{l}\text { Environmental } \\
\text { Studies }\end{array}$ & $2.22(.66)$ & $2.50(.71)$ & $2.23(.63)$ & $2.76(.62)$ & 1.95 & .133 \\
\hline Development & $3.00(.00)$ & $2.83(.24)$ & $2.60(.46)$ & $2.37(.73)$ & 3.23 & $.030^{*}$ \\
\hline
\end{tabular}

$* \mathrm{p}<.05 ; * * \mathrm{p}<.01 ; \mathrm{N} / \mathrm{A}:$ Not applicable.

\section{Discussion and Conclusions}

Drawing on the policy enactment theory, the present study assessed the enacted kindergarten curriculum in Ghana. In this section, the authors discuss four major findings from the study. First, the kindergarten teachers in the study focused on academics (Literacy/Numeracy and Environmental Studies) to the neglect of Physical Development and Psychosocial Skills. This is consistent with MOE's (2012) report that the Ghanaian kindergarten curriculum in practice "focused on an academic approach, contrary to the child-centered approach recommended by the intended curriculum"(p. 20). 
Sofo and Asola (2015) reported a sample of Ghanaian kindergarten teachers identified the lack of teachers' guides and manuals as major barriers to teaching movement and physical activity. Another study reported that a sample of Ghanaian early childhood preservice teachers were not adequately prepared to teach psychosocial skills to young children (Kankam \& Abroampa, 2016).

Second, class size and teaching experience were negatively correlated with the Psychosocial Skills subscale for KG1. The kindergarten curriculum in Ghana requires that psychosocial skills be integrated across the curriculum. The large class sizes for the teachers in the present study could be a contributing factor for the inability to teach psychosocial skills across the curriculum. Providing activities or opportunities that would allow teachers to integrate psychosocial skills with large class sizes is time consuming. However, investing in the development of psychosocial skills would yield high returns in future educational and employment outcomes especially among disadvantaged young people (Heckman, Stixrud, \& Urzua, 2006). The role of psychosocial skills in children's learning and development cannot be overemphasized. The negative correlation between teaching experience and the teaching of psychosocial skills may reflect the way experienced teachers themselves were taught. As MOE's (2012) report noted, their (experienced teachers) training was less relevant to kindergarten than to higher grade levels of education. In addition, the neglect of psychosocial skills could be attributed to cultural reasons. Ghana, like other Sub-Saharan countries, is a culturally communalistic society as against the individualistic Eurocentric formal education context in schools. Thus, parents view the home as a better setting for teaching psychosocial skills than the school. Rather, parents in Ghana value early education and consider the school's main role to be that of preparing children for academics (Bidwell \& Watine, 2014; Kabay, Wolf, \& Yoshikawa, 2017) that will provide opportunities for social mobility. The motivations of Ghanaians sending their children to school has changed very little since colonial times. As Foster (1965) succinctly put it, "Education, in practice, was valued for its cash return, and it remained virtually the only mode by which individuals could partially dissociate themselves from traditional society" (p. 64).

Third, male teachers were more likely than females to focus on Physical Development. The sport-oriented content related to physical development in the kindergarten curriculum may explain the likelihood of male teachers to focus on physical development (MOESS, 2006). Culturally, boys in the Ghanaian society are more likely than girls to participate in sport-oriented experiences in school. As Zeichner and Gore (1990) espoused, teacher candidates' early school experiences have stronger influences on their beliefs about teaching and learning than formal teacher education. 
Fourth, untrained teachers in KG1 were more likely than trained teachers with diplomas to implement the intended curriculum. Similarly, untrained KG2 teachers and trained teachers with bachelor's degrees differed on the implementations of the PS and PD subscales. Untrained teachers taught more topics than their professional counterparts perhaps, as Rovegno and Bandhauer (2017) noted, novice teachers think they must cover all topics in their lesson plan. Thus, they get through the materials in their lesson plans even if students do not respond appropriately. In contrast, experienced teachers would proceed to the next topic only if students respond appropriately to the preceding task or topic. The contradictory finding that untrained teachers in this study were more likely than trained teachers to implement the curriculum may be attributed to two plausible reasons. First, untrained teachers would be more concerned about job security than their trained counterparts and would more likely comply with the expectation to teach topics outlined in the curriculum, even if those topics do not align with their beliefs about what kindergarteners need to learn. Second, curriculum implementation is influenced by teachers' beliefs (Capel \& Blair, 2013) and perceived relevance of the curriculum (Kwarteng, 2018). Therefore, trained teachers would more likely than untrained teachers use their professional judgment to not teach topics (content) that they perceive to be inconsistent with their beliefs or less important to student development and learning.

The findings from the current study suggest three main conclusions. First, kindergarten teachers in this study showed characteristics that were like those observed in previous studies. For example, they focused on academics at the neglect of holistic development of the young child. The most neglected contents were psychosocial skills and physical development. Second, class size and teaching experience were negatively correlated with the Psychosocial Skills subscale for KG1. That is, veteran teachers in KG1 were less likely to view psychosocial skills as major focus of their teaching. Similarly, large class sizes served to inhibit the teaching of psychosocial skills in KG1. Finally, untrained teachers were more likely than their trained colleagues to teach more topics in their classrooms

\section{Implications for achieving congruence between the intended and enacted curriculum}

The findings of the present study have four implications for policy, teacher education and practice in achieving congruence between the intended and enacted kindergarten curricula. First, many $\mathrm{KG}$ teachers' training are less relevant to KG than to higher grade levels (MOE, 2012). Therefore, efforts should be made by preservice and in-service teachers to critically examine the KG curriculum. 
Second, teacher education programs need to consider preservice teachers' biography and help them to examine their beliefs and value orientations since early school experiences influence the development of one's perspectives to teaching and learning (Lortie, 1975, 2012; Zeichner \& Gore, 1990). For example, Zeichner and Gore (1990) asserted that what teacher candidates learn about teaching and learning as children in schools has a stronger influence on their beliefs about teaching than formal teacher education. This should continue with beginning teachers through relevant professional development which focuses on self-awareness and getting along with others. Some teachers observed that they had received no training in using the $\mathrm{KG}$ curriculum or the training they received was inadequate to support quality teaching and learning (MOE, 2102). Third, there is the need for Colleges of Education and Universities to provide training in early childhood education to fill the huge gap in KG classrooms with teachers certified in early childhood certification. Often teachers without early childhood certification have limited understanding of young children and see themselves as "didactic instructors rather than facilitators of learning" because of the way they themselves were trained (MOE, 2012:21). To bridge the gap between official content and content covered by participants in the present study, it is imperative that educators, policymakers, and curriculum planners stress the need and hold teachers accountable for the holistic education of young children. Finally, teacher induction for beginning teachers should be an integral part of the KG education. There is the tendency for experienced or veteran teachers to pressure beginning teachers to conform to the status quo, what Zeichner and Tabachnick (1981) referred to as the "washout effect."It is the period when the effect of the teacher education program diminishes due to school practices (Zeichner \& Tabachnick, 1981).

\section{Future Research}

The present study examined the enacted kindergarten curriculum in Ghana. It examined the content that KG teachers focused on in their classrooms- it did not assess the quality of the enacted curriculum. More research is needed to gain insight into the quality of the enacted curriculum, and to understand teachers' decisions regarding content coverage. First, future studies should include classroom observations that would examine pedagogical strategies teachers use in addition to the content taught. Second, the use of qualitative methodologies in future research is warranted. Interviews, for example, would allow future researchers to understand why teachers choose to teach

some topics but not others. Finally, replication of the study in other districts/municipalities/metropolitan school contexts in other regions of the country would allow 
policymakers and educational administrators to assess regional disparities in the enacted kindergarten curriculum nationwide.

\section{References}

Ball, S., Maguire, M., \& Braun, A. (2012). How schools do policy - policy enactments in secondary schools. Abingdon, Oxon: Routledge.

Bantwini, B.D. (2010). How teachers perceive the new curriculum reform: Lessons from a school district in the Eastern Cape Province, South Africa. International Journal of Educational Development, 30(1), 83-90.

Bidwell, K., \& Watine, L. (2014). Exploring early education problems in peri-urban settings in Africa: Final report. Newhaven, CT: Innovations for Poverty Action. Retrieved January 25, 2019 from http://www.poverty-action.org/study/exploring-early-education-programs-periurbansettings-africa-accra-ghana.

Boahin, P., \& Hofman, A.W.H. (2012). Implementation of innovations in higher education: The case of competency-based training in Ghana. Innovations in Education and Teaching International, 49 (3), 283-293.

Bouck, E. (2008). Factors impacting the enactment of a functional curriculum in self-contained crosscategorical programs. Education and Training in Developmental Disabilities, 43(3), 294-310. Retrieved November 14, 2018 from http://www.jstor.org/stable/23879792.

Brophy, J.E. 2000. Teaching. Educational practices series-1. Retrieved 4 January 2011. http://www.ibe.unesco.org/publications/EducationalPracticesSeriesPdf/prac01e.pdf.

Brouwer, N., \& Korthagen, F. (2005). Can teacher education make a difference? American Education Research Journal, 42(1), 153-224.

Bullard, J. (2012). Creating environments for learning: Birth to age eight. New Jersey: Upper Saddle River.

Burgeson, C.R., Wechsler, H., Brener, N.D., Young, J.C., \& Spain, C.C. (2001). Physical education and activity: Results from the school health policies and programs study 2000. Journal of School Health, 71, 279-293.

Cal, G. \& Thompson, D.R. (2014). The enacted curriculum as a focus of research. In Denise R. 
Thompson and Zalman Ussiskin, Enacted mathematics curriculum: A conceptual framework and research needs, pp. 1-19. Charlotte, NC: Information Age Publishing.

Capel, S. \& Blair, R. (2013). Why do physical education teachers adopt a particular way of teaching? In: Capel S and Whitehead M (eds) Debates in physical education. Abingdon, Oxon: Routledge, pp. 120-139.

Chapman, S., Wright, P.R., \& Pascoe, R. (2017). Content without context is noise: Looking for curriculum harmony in primary arts education in Western Australia. International Journal of Education and the Arts, 19(2). DOI: https://doi.org/10.18113/P8ijea1902.

Christensen, E. (2013). Micropolitical staffroom stories: Beginning health and physical education teachers' experiences of the staffroom. Teaching and Teacher Education, 30, 74-83. DOI: https://doi.org/10.1016/j.tate.2012.11.001.

Coburn, C. (2005). Shaping teacher sensemaking: School leaders and the enactment of reading policy. Education Policy, 19(3), 476-509. DOI: https://doi.org/10.1177/0895904805276143.

Cuban, L. (1992). What happens to reforms that last? The case of the junior high school. American Educational Research Journal, 29(2), 227-251.

DOI: https://doi.org/10.3102/00028312029002227.

Dietz, W.H. (1998). Health consequences of obesity in youth: Childhood predictors of adult disease. Paediatrics, 101(3 Pt. 2), 518-525.

Flores, M.A. (2005). Teachers' views on recent curriculum changes: Tensions and challenges. The Curriculum Journal, 16(3):401-413.

Foster, P. (1965). Education and social change in Ghana. London: Routledge \& Kegan Paul.

Fox, L., Hemmeter, M., Snyder, P., Binder, D.P., \& Clarke, S. (2011). Coaching early childhood special educators to implement a comprehensive model for promoting young children's social competence. Topics in Early Childhood Special Education, 31, 178-192.

Frost, J. L., Brown, P., Sutterby, J.A., \& Thornton, C.D. (2004). The developmental benefits of playground. Olney, MD: Association for Childhood Education International. 
Fullan, M. 2009. Large-scale reform comes of age. Journal of Educational Change, 10(2-3):101113. DOI: https://doi.org/10.1007/s10833-009-9108-z.

Gehrke, N.J., Knapp, M.S., \&Sirotnik, K.A. (1992). In search of the school curriculum. Review of Research in Education, 18, 51-110.

Ghana Education Service (2003). Handbook for UTDBE programme through distance education, Accra: GES.

Head Start (2012). Head start approach to school readiness. Retrieved November 15, 2018 from https://eclkc.ohs.acf.hhs.gov/school-readiness/article/head-start-approach-school-readinessoverview.

Heckman, J.J., Stixrud, J., \& Urzua, S. (2006). The effects of cognitive and noncognitive abilities on labor market outcomes and social behavior (No. w12006). National Bureau of Economic Research.

Hiebert, J., \& Grouws, D.A. (2007). The effects of classroom mathematics teaching on students' learning. In F. K. Lester (Ed.), Second handbook of research on mathematics teaching and learning (pp. 371-404). Charlotte, NC: Information Age Publishing.

Hunsader, P.D.,\& Thompson, D.R. (2014). Influence of mathematics curriculum enactment on student achievement. In Denise R. Thompson \& Zalman Usiskin (Eds.), Enacted Mathematics Curriculum, (pp. 47-73). Charlotte, NC: Information Age Publishing, Inc.

Kabay, S., Wolf, S., \& Yoshikawa, H. (2017). "So that his mind will open": Parental perceptions of preschool in urbanizing Ghana. International Journal of Educational Development, 57, 44-53. DOI: https://doi.org/10.1016/j.ijedudev.2017.08.013.

Kankam, G., \& Abroampa, W.K. (2016). Early childhood education pre-service teachers' pedagogical content knowledge in teaching psychosocial skills across the kindergarten curriculum in Ghana. Asia-Pacific Journal of Research in Early Childhood Education, 10(1), 67-86.

Kwaah, C. Y., \& Palojoki, P. (2018). Entry characteristics, academic achievement and teaching practices: A comparative study of two categories of newly qualified teachers in basic schools in Ghana. Cogent Education, 5, 1-19. DOI: https://doi.org/10.1080/2331186X.2018.1561144. 
Kruse, R. A., \& Roehrig, G. H. (2005). A comparison study: Assessing teachers' conceptions with the chemistry concepts inventory. Journal of Chemical Education, 82(8), 1246- 1251.

Kwarteng, J.T. (2018). Accounting teachers' quality of use of pre-tertiary accounting curriculum in Ghana's secondary schools. African Journal of Teacher Education, 7(2), 6790.DOI: https://doi.org/10.21083/ajote.v7i2.4157.

Lortie, D.C. (1975). Schoolteacher: A sociological study. Chicago, IL: University of Chicago Press.

Lortie, D.C. (2012). Schoolteacher: A sociological study (2 ${ }^{\text {nd }}$ Edition). Chicago, IL: University of Chicago Press.

Martyniuk, O. J., \& Tucker, P. (2014). An exploration of early childhood education students' knowledge and preparation to facilitate physical activity for preschoolers: A cross-sectional study. BMC Public Health, 14, 727. DOI: 10.1186/1471-2458-14-727.

Marzano, R.J. (2003). What works in schools: Translating research into action. Alexandria, VA: Association for Supervision and Curriculum Development.

McCoy, D.C., \& Wolf, S. (2018). Changes in classroom quality predict Ghanaian preschoolers' gains in academic and social-emotional skills. Developmental Psychology, 54(8), 1582-1599. DOI: http://dx.doi.org/10.1037/dev0000546.

Mereku, K.D. (1995). A comparison of the official primary mathematics curriculum in Ghana with the way in which it is implemented by teachers. (Unpublished Doctoral Dissertation). The University of Leeds, Leeds: United Kingdom.

Mereku, D. K. \& Mereku, C.W.K. (2015). Congruence between the intended and attained ICT curricula in Sub-Saharan Africa. Canadian Journal of Science, Mathematics and Technology Education, 15(1), 1-14. DOI: 10.1080/14926156.2014.992555.

Ministry of Education (2012). Education sector performance report. Accra: Ministry of Education.

Ministry of Education, Science \& Sports (2006). Curriculum for kindergarten (Kindergarten 1-2). Accra: MOESS.

Ministry of Education Science \& Sports (2007). Teaching syllabus for physical education (Primary 16). Accra: MOESS

Mize, J. \& Abell, E. (1996). Encouraging social skills in young children: Tips teachers 
can share with parents. Dimensions of Early Childhood, 2 (43), 15-23.

Moore, A. (2000). Teaching and Learning: Pedagogy, Curriculum and Culture. London: Routledge.

Onchwari, G. \& Keengwe, J. (2011). Examining the relationship of children's behavior to emotion regulation ability. Early Childhood Education Journal, 39(4), 279-284. DOI: 10.1007/s10643011-0466-9.

Porter, A. C. \& Smithson, J. L. (2001). Defining, developing, and using curriculum indicators. CPRE Research Report Series (RR-048 RR-048). Consortium for Policy Research in Education.

Raudenbush, S.W. (2008). Advancing educational policy by advancing research on instruction. American Educational Research Journal, 45(1), 206-230.

Remillard, J.T. \& Heck, D.J. (2014) Conceptualizing the enacted curriculum in mathematics education. In Denise R. Thompson \& Zalman Usiskin (Eds.), Enacted Mathematics Curriculum, (pp. (121-148). Charlotte, NC: Information Age Publishing, Inc.

Roehrig, G. H., Kruse, R.A., \& Kern, A. (2007). Teacher and school characteristics and their influence on curriculum implementation. Journal of Research in Science Teaching, 44(7), 883907.

Rovegno, I. \& Bandhauer, D. (2017). Elementary physical education: Curriculum and instruction( $2^{\text {nd }}$ Edition.). Burlington, MA: Jones \& Bartlett Learning.

Rowan, B., Camburn, E., \& Correnti, R. (2004). Using teacher logs to measure the enacted curriculum: A study of literacy teaching in third-grade classrooms. The Elementary School Journal, 105(1), 75-101.

Sabol, R. (2013). Seismic shifts in the education landscape: What do they mean for arts education and arts education policy? Arts Education Policy Review, 114(1), 33-45.

Sofo, S. \& Asola, E.F. (2015). Perceived barriers to teaching movement and physical activity to kindergarteners in Ghana. Journal of Education and Practice, 6(36), 134-140.

Son, J-W. \& Senk, S.L. (2014). Teachers' knowledge and the enacted mathematics curriculum. In Denise R. Thompson \& Zalman Usiskin (Eds.), Enacted Mathematics Curriculum, (pp. (75-95). Charlotte, NC: Information Age Publishing, Inc. 
Stein, M. K., Grover, B.W., \& Henningsen, M. (1996). Building student capacity for mathematical thinking and reasoning: An analysis of mathematical tasks used in reform classrooms. American Educational Research Journal, 33, 455-488.

Stein, M. K., Remillard, J., \& Smith, M. (2007). How curriculum influences student learning. In F. K. Lester, Jr. (Ed.), Second handbook of research on mathematics teaching and learning (pp. 319369). Reston, VA: National Council of Teachers of Mathematics.

Tabulawa, R. (2013). Teaching and learning in context: Why pedagogical reforms fail in SubSaharan Africa.

UNICEF (April 2012a). School readiness: Conceptual framework. UNICEF. New York, NY: UNICEF.

UNICEF (July 2012b). School readiness and transitions: A companion to the child friendly schools manual. UNICEF. New York, NY: UNICEF

United Nations (2013). Millennium development goals: 2013 report. Retrieved January 2, 2018 from http://www.un.org/millenniumgoals/pdf/report-2013/mdg-report-2013-english.pdf.

United Nations, (2015). Transforming our world: The 2030 agenda for sustainable development (A/RES/70/1). $\quad$ Retrieved December $22, \quad 2018$ from https://sustainabledevelopment.un.org/content/documents/21252030\%20Agenda\%20for\%20Sust ainable\%20Development\%20web.pdf.

Weiss, I. R., Pasley, J. D., Smith, P.S., Banilower, E. R., \& Heck, D.J. (2003). Looking inside the classroom: A study of K-12 mathematics and science education in the United States. Chapel Hill, NC: Horizon Research.

Weisz, E. (2001). A view of curriculum as opportunities to learn: An examination of curriculum enactment. Education, 107(2), 155-161

Wolf, S. (2017). The impacts of fast track transformational teacher training in Ghana. Preliminary results brief. Newhaven, CT: Innovations for Poverty Action. Retrieved January 29 from https://www.povertyaction.org/sites/default/files/publications/FTTT\%20Preliminary\%20Results $\% 20 \mathrm{v} 2-2 . \mathrm{pdf}$ 
Wolf, S., Aber, L. J., Behrman, J. R., \& Tsinigo, E. (2018). Experimental impacts of the "Quality preschool for Ghana" interventions on teacher professional well-being, classroom quality, and children's school readiness, Journal of Research on Educational Effectiveness, DOI: $10.1080 / 19345747.2018 .1517199$

Zeichner, K. G.,\& Gore, Y. J. (1990). Teacher socialization. In handbook of research on Teacher education (pp. 329-348). New York: MacMillan.

Zeichner, K. G. \& Tabachnick, R.B.(1981). The effects of university teacher education washed out by school experience? Journal of Teacher Education, 2, 7-11. 